
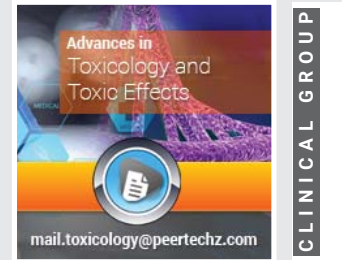

Research Article

\section{Distribution and interactions} of priority heavy metals

\section{with some antioxidant}

\section{micronutrients in inhabitants}

of a lead-zinc mining

community of ebonyi state,

\section{Nigeria}

\section{Bello H Tilako', Sylvester O Ogbodo2*, Innocent N \\ Okonkwo ${ }^{3}$, Imelda N Nubila ${ }^{4}$, Irene L Shuneba ${ }^{5}$, Enyinna Ogbonna ${ }^{6}$, Saidi Odoma ${ }^{6}$, Rebecca M Gali ${ }^{7}$, Bassey E \\ Bassey ${ }^{8}$ and Elvis N Shu ${ }^{4}$}

\section{${ }^{1}$ State Ministry of Health, Gombe, Gombe State, Nigeria}

${ }^{2}$ Department of Medical Biochemistry, Faculty of Basic Medical Sciences, College of Medicine, Enugu State University of Science \& Technology, Enugu, Nigeria

${ }^{3}$ Department of Medical Laboratory Science, University of Nigeria, Nsukka, Nigeria

${ }^{4}$ Department of Pharmacology and Therapeutics, College Medicine, University of Nigeria, Nsukka, Nigeria

${ }^{5}$ Faculty of Medical Sciences, College of Medicine, University of Nigeria Teaching Hospital, ItukuOzalla, Enugu State, Nigeria

${ }^{6}$ Department of Pharmacology and Therapeutics, Faculty of Basic Clinical Sciences, Kogi State University, Anyigba, Kogi State, Nigeria

${ }^{7}$ Department of Medical Laboratory Science, Faculty of Allied Health Sciences, University of Maiduguri, Borno State, Nigeria

${ }^{8}$ WHO Headquarters, Abuja, Nigeria
Received: 27 April, 2020

Accepted: 13 June, 2020

Published: 15 June, 2020

*Corresponding author: Sylvester O Ogbodo, Department of Medical Biochemistry, Faculty of Basic Medical Sciences, College of Medicine, Enugu State University of Science \& Technology, Enugu, Nigeria, E-mail: sylvester.ogbodo@esut.edu.ng

Keywords: Distribution; Interactions; Priority heavy metals; Micronutrient elements; Mining community

https://www.peertechz.com

Check for updates

\footnotetext{
Abstract

Background: Human exposure to xenobiotics, especially priority heavy metals (lead, cadmium, arsenic, mercury and chromium), is unavoidable because of their involvement in industrial applications, accumulation in the environment over time and non-biodegradability. Unfortunately, they induce unprecedented biochemical and pathological changes on those exposed to them, causing oxidative damages and organ toxicities.
}

Aim: This study investigated the frequencies of priority heavy metals and their impact on some micronutrient elements (copper, iron, zinc) in the blood of inhabitants of a lead-zinc mining community in southeastern Nigeria. 
Methods: Subjects, who were aged between 10 and 60 years, included 89 artisanal miners (occupationally-exposed), 61 non-miners living in the same community (environmentally-exposed) and 65 non-miners from a distant community (controls). Both priority heavy metals and the micronutrient elements were estimated using the atomic absorption spectrophotometric method.

Results: Results showed that all the studied priority heavy metals have frequencies higher than the WHO-recommended levels and their concentrations in occupationallyexposed subjects were significantly higher than their concentrations in both environmentally-exposed and control subjects. Likewise, their concentrations in environmentallyexposed subjects were significantly higher than those in the control subjects. It was also observed that the concentrations of the micronutrient elements in occupationallyexposed subjects were significantly lower than their concentrations in both environmentally-exposed and control subjects, showing strong negative correlations between these priority heavy metals and the micronutrient elements.

Conclusion: This study indicates that other priority heavy metals other than lead are prevalent in the studied area and these metals affect the absorption and metabolism of micronutrient elements and may also affect the antioxidant activities and other biological functions of the micronutrients.

\section{Introduction}

Heavy metals are naturally-occurring metallic elements with high atomic weight and density at least five times greater than that of water [1]. Some of these elements such as cobalt (Co), copper $(\mathrm{Cu})$, iron $(\mathrm{Fe})$, Nickel $(\mathrm{Ni})$, selenium $(\mathrm{Se})$, and zinc $(\mathrm{Zn})$ are actually necessary for humans in minute amounts while others such as arsenic (As), cadmium (Cd), chromium $(\mathrm{Cr})$, lead $(\mathrm{Pb})$ and mercury $(\mathrm{Hg})$ can damage living things even at low concentrations and tend to accumulate in the food chain [2]. The elements in the first group are the essential micronutrients - they are absolutely needed by the body even though in minute amounts. These micronutrients are known to play great roles in cellular metabolism including fetal growth and survival, anti-oxidation and cellular maintenance $[3,4]$. Particularly, zinc, copper and selenium are antioxidants known to be involved in reproduction. Zinc and copper increase sperm count and motility, and help to extend the functional life span of ejaculated spermatozoa [5] while selenium is an essential structural protein in spermatozoa [6]. Iron and copper are involved in hemoglobin synthesis while zinc and selenium are involved in immune development and maintenance, hence sometimes referred to as anti-infective antioxidants [7]. Those in the second group are the toxic elements that have been implicated in toxicity of many organs, especially the liver and the kidney [8-10]. Because of their high degree of toxicity and persistence in the environment, $\mathrm{As}, \mathrm{Cd}, \mathrm{Cr}, \mathrm{Pb}$ and $\mathrm{Hg}$ are commonly considered as priority heavy metals that are of public health importance [1,11]. They are highly hazardous and can negatively affect our health and environments when improperly managed, hence regarded as serious environmental pollutants. Four of these priority heavy metals $(\mathrm{As}, \mathrm{Cd}, \mathrm{Pb}, \mathrm{Hg})$ are among the ten major chemicals of concern [12]. Sources of these heavy metals in the environment include geogenic, industrial, agricultural, pharmaceutical, domestic effluents and the atmosphere [13].

Environmental pollution is very prominent in point source areas such as mining, foundries, smelters, and other metalbased industrial operations. In Enyigba community in Ebonyi State of Nigeria, environmental contamination and human exposure to heavy metals result from artisanal lead-zinc mining activities which have become a significant occupation among most of the inhabitants, both old and young. With such artisanal mining activities and the inappropriate storage of the mined products in their homes and heaps of the mining tails everywhere in the community [14], the inhabitants (both miners and non miners) are bound to be exposed to metal pollution. Earlier assessment of herbal preparations from the study area [15], suggests that there is possibility of heavy metal intoxication of the inhabitants in addition to attenuation of the phyto-potency of the preparations by the heavy metals. This is supported by earlier findings on the concentrations of these heavy metals in the soil, water and foods from this area and its environs [16-18].

Some studies [19-21], have evaluated the interactions between toxic elements and nutritional essential elements generally, while some [22-24], were particularly on leadexposed workers. Apart from these earlier studies, there is dearth of data on the frequencies and interactions between priority heavy metals and nutritional elements in point source area like a mining community, comparing miners and nonminers living in the same community. In the present study, we investigated for the first time, all five priority heavy metals in the blood of occupationally-exposed and environmentallyexposed subjects in a lead-zinc mining community, and their interactions with some essential micronutrient elements. Elucidating such interactions is essential for health risk assessment and management of chemical mixtures. Also, understanding the interactions in both occupationally and environmentally-exposed individuals will help government of the day to enact legislations enforcing proper disposal mechanisms for the products of both artisanal and formal mining activities and possibly plan effective phyto-remediation of the mining areas. These will go a long way in safeguarding the lives of the inhabitants of these mining communities.

\section{Materials and methods}

\section{Ethical considerations}

Ethical clearance for this study was sought and obtained from the Health Research Ethics Committee of the College of Medicine, University of Nigeria Teaching Hospital, ItukuOzalla, Enugu, Nigeria. Further ethical clearance was obtained from the State Ministry of Health, Abakaliki, Ebonyi State, Nigeria. The subjects gave their informed consent after thorough explanation of the importance and procedures for the study.

\section{Study area}

Enyigba mining community is the largest and most active among mining sites in Abakaliki mining area. The Abakaliki mining area lies between latitude $6^{0} 8^{1} \mathrm{~N}$ and $6^{0} 24^{1}$ and longitudes $8^{\circ} 05^{1} \mathrm{~S}$, with a prevailing climate condition of high

Citation: Tilako BH, Ogbodo SO, Okonkwo IN, Nubila IN, Shuneba IL, et al. (2020) Distribution and interactions of priority heavy metals with some antioxidant micronutrients in inhabitants of a lead-zinc mining community of ebonyi state, Nigeria. Adv Toxicol Toxic Effects 4(1): 011-0017.

DOI: https://dx.doi.org/10.17352/atte.000009 
temperatures and humidity for more than half the year and mangrove and freshwater swamp vegetation. The inhabitants are mainly subsistent farmers with yam and plantain as their staple foods, with oil palm bush and indigenous trees of nutritional, economic, medicinal and cultural importance. The Abakaliki lead-zinc is believed to be of hydrothermal origins emplaced at a temperature of about $140^{\circ} \mathrm{C}$ [17]. The region includes Abakaliki town (the state capital of Ebonyi State in the south eastern part of Nigeria) and the highly mineralized rural community (Enyigba) which is about $14 \mathrm{~km}$ south of the metropolis. Ezzamgbo, which is about $25 \mathrm{~km}$ from the study area, with no history of mining activities was used as a control community.

\section{Subjects}

A total of 215 subjects (aged between 10 and 60 years) were recruited for the study, comprising 89 artisanal mine workers (occupationally-exposed), 61 non-mine workers but living in the community (environmentally-exposed) and 65 subjects who lived $25 \mathrm{~km}$ away from the mining community who were not involved in any mining activity (controls).

\section{Sample collection and analysis}

Four milliliters $(4.0 \mathrm{ml})$ of venous blood was collected from each subject into sequestrene containers for heavy metal analysis. The separated plasma samples were stored frozen at $-80^{\circ} \mathrm{C}$ till day of analysis. The heavy metals comprising priority heavy metals [Arsenic, Cadmium, Chromium, Lead, Mercury) and essential elements (Copper, Iron, Zinc) were estimated by flame atomic absorption spectrometry using FS240AA Atomic Absorption Spectrophotometer (Agilent Technologies, USA) according to the method of American Public Health Association [25].

\section{Data analyses}

Data were analyzed using the statistical package for social sciences (SPSS). Statistical significance was taken to be $\mathrm{p}<0.05$ in all the analyses.

\section{Results}

Table 1 represents the frequencies of the priority heavy metals in the study participants in comparison with the WHO recommended limits. $\mathrm{Pb}$ was the most frequent with 148 out of 150 participants $(98.66 \%)$ with limits of $10 \mu \mathrm{g} / \mathrm{dl}$ and above. This was followed by Cd (56.66\%) and As (54.00\%) based on their respective recommended limits.

Table 2 represents the blood levels of priority heavy metal levels in the study population. The mean Arsenic (As), Cadmium (Cd), Chromium (Cr), Lead (Pb), Mercury (Hg) levels in the occupationally-exposed and environmentally-exposed individuals were significantly higher $(\mathrm{p}<0.001$ for each except $\mathrm{Cr}$ with $\mathrm{p}<0.01$ for the environmentally-exposed) when compared with the mean levels in the corresponding controls. Meanwhile, the Copper ( $\mathrm{Cu})$, Iron (Fe), and Zinc ( $\mathrm{Zn})$ mean levels in the occupationally-exposed and environmentallyexposed individuals were significantly lower $(p<0.001$ for
Table 1: Frequencies of blood priority heavy metals in inhabitants of Enyigba study community.

\begin{tabular}{|c|c|c|c|}
\hline Heavy metals & Recommended limit & $\begin{array}{c}\text { Frequencies } \\
\text { (above WHO limits) }\end{array}$ & Percentage (\%) \\
\hline $\mathrm{Pb}(\mu \mathrm{g} / \mathrm{dl})$ & $<10 \mu \mathrm{g} / \mathrm{dl}$ & 148 & 98.66 \\
\hline $\mathrm{Cd}(\mu \mathrm{g} / \mathrm{l})$ & $0-5 \mu \mathrm{g} / \mathrm{l}$ & 85 & 56.66 \\
\hline $\mathrm{As}(\mathrm{ng} / \mathrm{ml})$ & $0-12 \mathrm{ng} / \mathrm{ml}$ & 81 & 54.00 \\
\hline $\mathrm{Hg}(\mu \mathrm{g} / \mathrm{l})$ & $<10 \mu \mathrm{g} / \mathrm{l}$ & 70 & 46.66 \\
\hline $\mathrm{Cr}(\mu \mathrm{g} / \mathrm{ml})$ & $<1.4 \mu \mathrm{g} / \mathrm{ml}$ & 20 & 13.33 \\
\hline
\end{tabular}

Table 2: Mean (SD) levels of blood heavy metals in the study population.

\begin{tabular}{|c|c|c|c|}
\hline Heavy metals & $\begin{array}{c}\text { Occup. Exposed } \\
\mathbf{n = 8 9} \\
\text { Mean (SD) }\end{array}$ & $\begin{array}{c}\text { Environ. Exposed } \\
\mathbf{n = 6 1} \\
\text { Mean (SD) }\end{array}$ & $\begin{array}{c}\text { Control } \mathbf{n = 5 0} \\
\text { Mean (SD) }\end{array}$ \\
\hline $\mathrm{Pb}(\mu \mathrm{g} / \mathrm{dl})$ & ${ }^{a} 42.30(10.90)^{\star \star}$ & $28.66(9.12)^{\star \star}$ & $4.76(2.16)$ \\
\hline $\mathrm{Zn}(\mu \mathrm{g} / \mathrm{dl})$ & ${ }^{a} 45.44(4.67)^{\star \star}$ & $61.64(5.98)^{\star \star}$ & $83.51(15.54)$ \\
\hline $\mathrm{Fe}(\mu \mathrm{g} / \mathrm{dl})$ & ${ }^{a} 29.54(4.23)^{\star \star}$ & $41.97(7.44)^{\star \star}$ & $55.00(23.19)$ \\
\hline $\mathrm{Hg}(\mu \mathrm{g} / \mathrm{L})$ & $10.00(7.26)^{\star \star}$ & $9.31(8.65)^{\star \star}$ & $3.44(2.58)$ \\
\hline $\mathrm{Cd}(\mu \mathrm{g} / \mathrm{L})$ & $8.80(7.56)^{\star \star}$ & $7.31(6.38)^{\star \star}$ & $2.86(1.52)$ \\
\hline $\mathrm{Cu}(\mu \mathrm{g} / \mathrm{dl})$ & $a 7.38(3.72)^{\star \star}$ & $10.36(7.03)^{\star \star}$ & $12.56(2.63)$ \\
\hline $\mathrm{Cr}(\mu \mathrm{g} / \mathrm{ml})$ & ${ }^{a} 0.15(0.25)^{\star \star}$ & $0.07(0.12)^{\star}$ & $0.04(0.04)$ \\
\hline $\mathrm{As}(\mathrm{ng} / \mathrm{ml})$ & ${ }^{a} 15.00(7.19)^{\star \star}$ & $9.55(7.19)^{\star \star}$ & $4.44(3.33)$ \\
\hline
\end{tabular}

Occup and Environ vs Controls: ${ }^{*} \mathrm{p}<0.01,{ }^{\star \star} \mathrm{p}<0.001$; Occup. vs Environ: ${ }^{\mathrm{a} p}<0.001$

each) when compared with the controls. Furthermore, the mean levels of $\mathrm{As}, \mathrm{Cr}$ and $\mathrm{Pb}$ in the occupationally-exposed individuals were significantly higher ( $\mathrm{p}<0.001$ for each) when compared with their mean levels in the environmentallyexposed individuals. Also, the mean levels of $\mathrm{Cu}, \mathrm{Fe}$ and $\mathrm{Zn}$ in the occupationally-exposed individuals were significantly lower ( $p<0.001$ for each) when compared with their mean levels in the environmentally-exposed individuals.

The mean levels of blood priority heavy metals in the study population according to gender are presented in Table 3. The mean levels of $\mathrm{As}, \mathrm{Cd}, \mathrm{Cr}, \mathrm{Hg}$, and $\mathrm{Pb}$ in the occupationallyexposed males were significantly higher $(\mathrm{p}<0.001$ for each, except $\mathrm{Cr}$ with $\mathrm{P}<0.05)$, whereas the mean levels of $\mathrm{Cu}, \mathrm{Fe}$, and $\mathrm{Zn}$ were significantly lower ( $\mathrm{p}<0.001$ for each) when compared with their mean levels in the corresponding male controls. The mean levels of priority heavy metals in the occupationallyexposed females were equally significantly higher, and the mean levels of the essential elements were significantly lower ( $p<0.001$ for each) when compared with their mean levels in the female control individuals. Likewise, mean levels of priority heavy metals in environmentally-exposed males and females were significantly higher while their essential elements were significantly lower when compared with their corresponding controls.

The Spearman correlations between blood priority heavy metals of the study population are presented in Table 4 . There were significant positive correlations between blood $\mathrm{Pb}$ and each of $\mathrm{Hg}(\mathrm{r}=0.327, \mathrm{p}=0.000)$, As $(\mathrm{r}=0.537, \mathrm{p}=0.000)$, Cd $(\mathrm{r}=0.352, \mathrm{p}=0.000)$ and $\mathrm{Cr}(\mathrm{r}=0.183, \mathrm{p}=0.009)$. There were also significant correlations between $\mathrm{Cd}$ and $\mathrm{Hg}(\mathrm{r}=0.402$, 
Table 3: Mean (SD) levels of blood priority heavy metals of the study population according to gender.

\begin{tabular}{|c|c|c|c|c|c|c|}
\hline Metal & Occupationally & Exposed & Environmentally & Exposed & Control & \\
\hline & Males & Females $n=39$ & Males & Females $n=38$ & Males & $\begin{array}{c}\text { Females } \\
n=22\end{array}$ \\
\hline $\mathrm{Pb}$ & $41.89(10.25)^{\star \star \star}$ & $42.24(11.84)^{\star \star \star}$ & $31.07(9.43)^{\star \star \star}$ & $27.78(9.54)^{\star \star \star}$ & $4.97(2.48)$ & $4.49(1.71)$ \\
\hline $\mathrm{Zn}$ & $\begin{array}{c}46.16 \\
(4.54)^{\star \star \star}\end{array}$ & $44.92(4.79)^{\star \star \star}$ & $\begin{array}{c}60.84 \\
(6.69)^{\star \star \star}\end{array}$ & $62.19(5.70)^{\star \star \star}$ & $84.12(18.35)$ & $82.46(11.58)$ \\
\hline $\mathrm{Fe}$ & $\begin{array}{c}29.77 \\
(3.92)^{\star \star \star}\end{array}$ & $29.27(4.71)^{\star \star \star}$ & $\begin{array}{c}41.60 \\
(7.57)^{\star \star \star}\end{array}$ & $\begin{array}{l}41.98 \\
(7.71)\end{array}$ & $62.98(25.08)$ & $43.38(14.72)$ \\
\hline $\mathrm{Hg}$ & $\begin{array}{c}10.70 \\
(7.78)^{\star \star \star}\end{array}$ & $9.10(6.61)^{\star \star}$ & $\begin{array}{c}11.17 \\
(8.63)^{\star \star \star}\end{array}$ & $\begin{array}{c}8.13 \\
(8.43)^{\star}\end{array}$ & $2.82(2.10)$ & $\begin{array}{c}4.23 \\
(3.03)\end{array}$ \\
\hline $\mathrm{Cd}$ & $\begin{array}{c}9.62 \\
(7.50)^{\star \star \star}\end{array}$ & $7.84(7.68)^{\star \star}$ & $\begin{array}{c}7.39 \\
(6.49) \star \star\end{array}$ & $7.08(6.19)^{\star \star}$ & $2.71(1.42)$ & $\begin{array}{c}3.09 \\
(1.70)\end{array}$ \\
\hline $\mathrm{Cu}$ & $\begin{array}{c}7.71 \\
(3.78)^{\star \star \star}\end{array}$ & $7.08(3.72)^{\star \star \star}$ & $\begin{array}{c}9.98 \\
(5.30)^{\star \star}\end{array}$ & $\begin{array}{l}10.60 \\
(7.91)\end{array}$ & $12.92(2.51)$ & $11.95(2.71)$ \\
\hline $\mathrm{Cr}$ & $\begin{array}{c}0.16 \\
(0.26)^{\star}\end{array}$ & $\begin{array}{c}0.14 \\
(0.23)\end{array}$ & $\begin{array}{c}0.08 \\
(0.13)\end{array}$ & $\begin{array}{c}0.05 \\
(0.11)\end{array}$ & $0.04(0.04)$ & $\begin{array}{l}0.04 \\
(0.04)\end{array}$ \\
\hline As & $\begin{array}{c}15.32 \\
(6.97)^{\star \star \star}\end{array}$ & $14.16(7.14)^{\star \star \star \star}$ & $\begin{array}{c}10.45 \\
(7.11)^{\star \star \star}\end{array}$ & $\begin{array}{c}9.55 \\
(8.01)^{\star}\end{array}$ & $4.18(3.47)$ & $\begin{array}{c}4.71 \\
(3.27)\end{array}$ \\
\hline
\end{tabular}

Males and Females vs corresponding controls: ${ }^{\star} \mathrm{p}<0.05, \quad * \star \mathrm{p}<0.01, \quad{ }^{\star \star *} \mathrm{p}<0.001$.

$\mathrm{p}=0.000)$, and between As and each of $\mathrm{Hg}(\mathrm{r}=0.213, \mathrm{p}=0.002)$ and $\operatorname{Cr}(\mathrm{r}=0.159, \mathrm{p}=0.024)$.

Table 5 presents correlations between the blood priority heavy metals levels and some essential trace elements in the study population. There were significant negative correlations between blood levels of the priority heavy metals and the trace elements $(\mathrm{Zn}, \mathrm{Fe}, \mathrm{Cu})$, except between $\mathrm{Hg}$ and $\mathrm{Cu}(\mathrm{r}=-0.046, \mathrm{p}$ $=0.5180)$; and between $\mathrm{Cr}$ and $\mathrm{Cu}(\mathrm{r}=-0.137, \mathrm{p}=0.053)$.

\section{Discussion}

Although lead and other WHO priority heavy metals (mercury, arsenic, cadmium and chromium) induce physiological, biochemical and behavioral disturbances of much pathological magnitude in humans, exposure to these xenobiotics is unavoidable because of its accumulation in the environment and use in industrial application [26]. Being present in contaminated water, air, soil, food and dust, heavy metals are mostly absorbed by the lungs and gastrointestinal tract [27]. The results of this study revealed that the frequencies of the priority heavy metals - lead $(\mathrm{Pb})$, mercury $(\mathrm{Hg})$, cadmium (Cd), chromium ( $\mathrm{Cr}$ ) and arsenic (As) in occupationally-exposed subjects were above their recommended limits and also significantly higher when compared with environmentally-exposed and control subjects. These findings are in agreement with some earlier studies on blood heavy metal concentrations in human subjects in similar environments [21,24,28]. However, Ji, et al. [29] reported lower blood lead levels and other heavy metals amongst children. This difference may be attributed to length of exposure of these subjects to the metals' sources. This opinion sounds plausible because heavy metals are known to be non-biodegradable with long biological half-life, making them to accumulate over time [30]. Furthermore, the study also indicates that environmentally-exposed subjects are at risk of heavy metal toxicity and micronutrient deficiency given the significant differences between the values of these metals in this group and those in the control group. In biological systems, heavy
Table 4: Correlation between the blood priority heavy metals.

\begin{tabular}{|c|c|c|c|c|c|}
\hline Heavy Metals & $\begin{array}{c}\mathbf{P b} \\
\mathbf{r}(\boldsymbol{P} \text {-value })\end{array}$ & $\begin{array}{c}\text { Cd } \\
\mathbf{r}(\boldsymbol{P} \text {-value })\end{array}$ & $\begin{array}{c}\text { As } \\
\mathbf{r}(\boldsymbol{P} \text {-value })\end{array}$ & $\begin{array}{c}\mathbf{H g} \\
\mathbf{r}(\boldsymbol{P} \text {-value })\end{array}$ & $\begin{array}{c}\mathbf{C r} \\
\mathbf{r}(\boldsymbol{P} \text {-value })\end{array}$ \\
\hline $\mathrm{Pb}(\mu \mathrm{g} / \mathrm{dl})$ & - & - & - & - & - \\
\hline $\mathrm{Cd}(\mu \mathrm{g} / \mathrm{L})$ & $\begin{array}{l}0.352 \\
(0.000)\end{array}$ & - & - & - & - \\
\hline $\mathrm{As}(\mathrm{ng} / \mathrm{ml})$ & 0.537 & 0.126 & - & - & - \\
\hline $\mathrm{Hg}(\mu \mathrm{g} / \mathrm{L})$ & $(0.000)$ & $(0.076)$ & - & - & \\
\hline & 0.327 & 0.402 & 0.213 & - & - \\
\hline $\mathrm{Cr}(\mu \mathrm{g} / \mathrm{ml})$ & $(0.000)$ & $(0.000)$ & $(0.002)$ & - & \\
& 0.183 & 0.090 & 0.159 & 0.099 & - \\
\hline
\end{tabular}

Table 5: Correlation between priority heavy metals and the trace elements in the study population.

\begin{tabular}{|c|c|c|c|}
\hline Heavy metals & Zn r (p values) & Fe r ( $p$ values) & Cu r ( p values) \\
\hline $\mathrm{Pb}$ & $-0,789(0.000)$ & $-0.637(0.000)$ & $-0.360(0.000)$ \\
\hline $\mathrm{Hg}$ & $-0.291(0.000)$ & $-0.235(0.000)$ & $-0.046(0.518)$ \\
\hline $\mathrm{As}$ & $-0.500(0.000)$ & $-0.417(0.000)$ & $-0.206(0.003)$ \\
\hline $\mathrm{Cd}$ & $-0,321(0.000)$ & $-0.246(0.004)$ & $-0.145(0.041)$ \\
\hline $\mathrm{Cr}$ & $-0.171(0.015)$ & $-0.144(0.042)$ & $-0.137(0.053)$ \\
\hline
\end{tabular}

metals have been reported to affect cellular organelles and components such as cell membrane, mitochondria, lysosome, endoplasmic reticulum, nuclei and some enzymes involved in metabolism, detoxification and damage repair - antioxidant activities [31]. These metal ions were found to interact with cell components such as DNA and nuclear proteins, causing DNA damage and conformational changes that may lead to oxidative damage - cell cycle modification, carcinogenesis or apoptosis [32]. Several studies [33,34] have demonstrated that reactive oxygen species (ROS) production and oxidative stress play a key role in the toxicity and carcinogenicity of priority heavy metals. In a study with plants [35], it was demonstrated that the magnitude of damages caused by these heavy metals depended on the heavy metal and the tolerance of plant species, and tolerance in this context is a function of oxidative status. Because of their high degree of toxicity, these five

Citation: Tilako BH, Ogbodo SO, Okonkwo IN, Nubila IN, Shuneba IL, et al. (2020) Distribution and interactions of priority heavy metals with some antioxidant micronutrients in inhabitants of a lead-zinc mining community of ebonyi state, Nigeria. Adv Toxicol Toxic Effects 4(1): 011-0017.

DOI: https://dx.doi.org/10.17352/atte.000009 
elements rank among the WHO priority heavy metals that are of great public health significance. They are all environmental pollutants, and also systemic toxicants when absorbed, that are capable of inducing multiple organ damage even at low levels of exposure. In the present study, interaction between the priority heavy metals revealed a significant positive correlation between $\mathrm{Pb}$ and $\mathrm{Hg}, \mathrm{Cd}, \mathrm{As}, \mathrm{Cr}$ respectively, which agrees with earlier studies $[36,37]$. The biological explanations to the reported correlations in humans are not yet clear and may need some further studies for clarification. However, it is possible that absorptions of these priority metals are interdependent or synergistic.

This study showed that blood levels of studied micronutrients - zinc, iron and copper, were significantly lower in occupationally-exposed subjects when compared with the levels obtained from environmentally-exposed and control subjects. This result is similar to some earlier studies $[21,38]$, that reported elevated blood levels of priority heavy metals amongst subjects with low essential trace elements. However, some studies [24,39], reported no association between priority heavy metals exposure and trace elements, while some [22], reported significant positive correlation between blood lead levels and zinc levels. The disagreement between these study groups may, in part, be attributed to the levels of these heavy metals in the soil and length of exposure of the subjects. Moreover, it is possible that decreased intake of divalent antioxidants, like iron and zinc, is a major factor that contributes to increased absorption and toxicities of these priority heavy metals. This is because an iron transporter divalent metal transporter 1 (DMT-1), found in the duodenum and other body cells, are known to have high affinity for the priority heavy metals as the divalent micronutrient elements [40]. Thus, if there is high concentration of the priority heavy metals in the environment, absorption of the micronutrients is highly reduced and where there is deficiency of micronutrients in the environment, absorption of the priority metals will increase. This increased absorption of priority heavy metals for any of the reasons above or others yet to be known may have accounted for the strong negative correlation between the priority heavy metals and the antioxidant micronutrients observed in this study. The resultant or fundamental low blood levels of the micronutrients in this study area will not only encourage increased absorption and toxicity of these priority heavy metals but also interfere with the biological and physiological functions of the body by encouraging oxidative damage. Iron, zinc and copper are essential trace elements that exert numerous biochemical and physiological functions for the maintenance of life and health and also act as antioxidants that prevent tissue damage. Iron is very essential in the production of red blood cells, copper is an integral component of many metalloenzymes, most of which help to inactivate free radicals - antioxidant property [41] and with iron, it is very essential for the formation of haemoglobin. Furthermore, zinc is an integral component of more than 300 different metalloenzymes where it is needed for the functioning of these enzymes, playing vital role in enormous number of biological processes, including metabolism of macro and micronutrients and improvement of immune system $[42,43]$. With derangement in these functions, many life complications are expected in the environment For instance, deficiency of zinc has been implicated in many untoward pregnancy outcomes including stillbirth, preterm birth, small-for-age birth, increased infant mortality, stunted growth and impaired sexual maturity [44-46], while iron and copper deficiencies are known causes of anemia and increased susceptibility to infection due to poor immune functions [47]. Fortunately, the affected functions can be ameliorated by supplementary intake of the deficient micronutrients since animal studies [48], have shown that adequate dietary intake of zinc, iron, copper and calcium reduced the severity of lead toxicity by decreasing the blood levels of lead, altering its absorption or restoring the lead-induced biological alterations. Particularly, a lead-zinc interaction has been observed at the absorptive as well as enzymatic sites [21]. Zinc is essential for cellular membrane integrity and metabolism as a central part of over 300 enzymes and proteins [49] and possesses antioxidant properties due to its requirement for superoxide dismutase (SOD) activity. Therefore, zinc not only reduces lead-induced oxidative stress, but also competes with lead for similar binding sites [21]. Competitive binding to metallothioneinlike transport protein in the rat duodenum demonstrates the ability of zinc to reduce lead absorption and toxicity. Thus, zinc supplementation was found to reverse the inhibition of the activity of blood $\partial$-amino levulinic acid dehydratase (ALAD) by lead, as it competes for and effectively reduces the availability of binding sites for lead uptake [21,24]. Furthermore, invitro studies had indicated that lead not only impairs iron binding to transferrin, but also suppresses its synthesis thus decreasing mRNA and protein levels [50]. Also, Klauder and Petering [51] had earlier observed that many characteristics of anemia due to lead are similar to those of copper deficiency and postulated that lead may induce copper deficiency and this will interfere with iron metabolism and utilization. Copper is known to have a role in the absorption of iron because the oxidation of ferrous iron to ferric state in haem synthesis is done by ceruloplasmin. On the other hand, high levels of blood lead was found to reduce the copper ceruloplasmin levels in rats while a decreased dietary copper level was associated with increased erythrocytes lead concentration [52]. Therefore, the depletion of copper in this study may cause impaired iron absorption and contribute to the iron deficiency. In plants, heavy metals are known to alter nutrient uptake processes and antioxidant systems of forage grasses including alterations in the amino acid metabolism, photosynthetic system, syntheses of chlorophyll and carotenoids and in the cell structure [53,54]. Thus, it is suspected that forage grasses whose contents of $\mathrm{Cu}$ and $\mathrm{Zn}$ are reduced when cultivated in the presence of toxic elements like $\mathrm{Cd}$ and $\mathrm{Pb}$ may have limited growth and therefore inefficient if used in phyto-remediation of environments with high heavy metals concentrations [55].

Interaction between other priority heavy metals $(\mathrm{Hg}$, As, $\mathrm{Cd}$ and $\mathrm{Cr}$ ) and major trace elements $(\mathrm{Zn}, \mathrm{Fe}$ and $\mathrm{Cu}$ ) was also found in humans, and in the milk of nursing mothers [36]. The study [36], reported significant negative correlations between some priority heavy metals $(\mathrm{Hg}, \mathrm{As}, \mathrm{Cd}, \mathrm{Cr})$ and the trace elements $(\mathrm{Zn}, \mathrm{Fe}, \mathrm{Cu})$ respectively which was in agreement with the present study and some previous studies [37,56]. 
Brzoska and Jakoniuk [57], were of the opinion that zinc status of the body is important in the development of cadmium toxicity. Increased zinc supply may therefore reduce cadmium absorption and accumulation and prevent or reduce its adverse effects, whereas zinc deficiency as recorded in the present study can intensify $\mathrm{Cd}$ accumulation and toxicity.

Lastly, inter gender analysis of priority heavy metals results in this study established that blood lead levels were higher in females of occupationally-exposed than males, whereas other priority heavy metals both in occupationally and environmentally-exposed subjects were higher in males than the females. This finding was in agreement with Ji, et al. [29], who reported higher blood lead levels in females than in males amongst children but disagreed with Counter, et al. [58], who reported higher blood lead levels and other priority heavy metals in males than females. While this area needs further study for full elucidation and articulation to adduce any biochemical or physiological reasons for these differences, it is possible that the differences may have to do with the levels of antioxidant elements in the different study groups.

\section{Conclusion}

The results of this study indicate that other priority heavy metals, apart from lead, are also prevalent in the studied area and in higher frequencies than WHO recommendations. The results also showed negative correlations between the priority heavy metals and the antioxidant micronutrients, indicating that these priority heavy metals can affect the absorption and metabolism of the micronutrients and therefore the antioxidant activities and other biological functions of the micronutrient elements. Unfortunately, the results also indicate that both occupationally-exposed and environmentally-exposed subjects are prone to the adverse effects of these priority heavy metals because the values of both priority heavy metals and antioxidant micronutrients from the two groups were significantly different from the values obtained from control subjects. It is therefore expected that if adequate precautionary measures are not put in place to safeguard the lives of the inhabitants of this area, their health status will be jeopardized.

\section{References}

1. Tchounwou PB, Yedjou CG, Patlolla AK, Sutton DJ (2012) Heavy metal toxicity and the environment. EXS 101: 133-164. Link: https://bit.ly/3dYkVyh

2. Dufus JH (2002) Heavy metals- a meaningless term? Pure Appl Chem 74: 793 807. Link: https://bit.ly/3fu2PEN

3. Keen CL, Clegg MS, Hanna LA, Lanoue L, Rogers JM et al. (2003) The plausibility of micronutrient deficiencies being a significant contributing factor to the occurrence of pregnancy complications. J Nutr 133: 1597s-1605s. Link: https://bit.ly/37tCfsu

4. Ogbodo SO, Okaka AN, Nwagha UI (2014) Parity may determine levels of some antioxidant minerals in pregnancy: An experience from rural South-Eastern Nigeria. J Basic Clin Reprod Sci 3: 27-31. Link: https://bit.ly/3e4IRRR

5. Bedwal RS, Bahuguna A (1994) Zinc, copper and selenium in reproduction Experientia 50: 626-640. Link: https://bit.ly/2MXVPUf

6. Foresta C, Flohe L, Garolla A, Ursini F, Maiorino M, et al. (2002) Male fertility is linked to the selenoprotein phospholipids hydroperoxide glutathione peroxidase. Biol Reprod 67: 967-971. Link: https://bit.ly/3d1diWv
7. Ogbodo SO, Okaka ANC, Nwagha UI (2013a) Anti-infective antioxidant minerals levels in uncomplicated pregnancy in some rural communities of South East Nigeria. J Med Nutr Nutraceut 2: 52-57. Link: https://bit.ly/3d1dbdx

8. Dioka CE, Orisakwe OE, Adeniyi FA, Meludu SC (2004) Liver and renal function tests in artisans occupationally exposed to lead in mechanic village in Nnewi, Nigeria. Intern J Environ Res Public Health 1: 21-25. Link: https://bit.ly/2N2aXjm

9. Zhang Z, Gao X, Guo M, Jiang H, Cao Y, et al. (2017) The protective effect of baicalin against lead-induced renal oxidative damage in mice. Biol Trace Elem Res 175: 129-135. Link: https://bit.ly/37ukZmY

10. Orr SE, Bridges CC (2017) Chronic kidney disease and exposure to nephrotoxic metals. Intern J Mol Sci 18: 1039-1049. Link: https://bit.ly/2CbqYBL

11. He B, Yun Z, Shi JB, Jiang GB (2013) Research progress of heavy metal pollution in China: Sources, analytical methods, status, and toxicity. Chinese Science Bulletin 58: 134-140. Link: https://bit.ly/3e3wGTX

12. WHO (2011) 10 chemicals of major public health concern. Link: https://bit.ly/2YySVLb

13. He ZL, Yang XE, Stofella PJ 2005) Trace elements in agroecosystems and impacts on the environment. J Trace Elem Med Biol 19: 125-140. Link: https://bit.ly/3hvhZvl

14. Tilako BH, Otuu FC, Bassey EB and Shu EN (2019) Blood-lead levels among inhabitants of Enyigba lead-zinc mining community of Ebonyi State, Nigeria: Indications of occupational and environmental health hazards. Adv Clin Toxicol 4: 000162. Link: https://bit.ly/2N2bm5m

15. Shu EN, Otuu FC, Maduka IC, Tilako BH, Nwadinigwe AO, et al. (2019) Public health implications of continuous ethnomedical use of some plant species encountered in Enyigba lead-zinc mining community of Ebonyi State, Nigeria. IOSR J Environ Sci Toxicol Food Technol 13: 62-68. Link: https://bit.ly/3d6TrFf

16. Ezeh HN, Chukwu E (2011) Small scale mining and heavy metals pollution of agricultural soils: The case of Ishiagu Mining District, South Eastern Nigeria. J Geol Mining Res 3: 87-104. Link: https://bit.ly/3hsPTk6

17. Oti Wilberforce JO, Nwabue FI (2013) Uptake of Heavy Metals by Dioscorea rotundata (White Yam) and Ipomoea batatas (Sweet Potato) from Enyigba Lead-Zinc Derelict. Environ Pollut 2: 79-84. Link: https://bit.ly/3hviq8X

18. Okogbue CO, Ukpai SN (2013) Evaluation of trace element contents in groundwater in Abakaliki metropolis and around the abandoned mine sites in the southern parts, Southeastern Nigeria. Environ Earth Sci 70: 3351-3362. Link: https://bit.ly/2MVQCfR

19. Abdulla M, Chmielnicka J (1990) New aspects on the distribution and metabolism of essential trace elements after dietary exposure to toxic metals. Biol Trace Elem Res 23: 25-53. Link: https://bit.ly/3e36IQH

20. Lopez AM, Prieto MF, Miranda M, Castillo C, Hernandez J, et al. (2004) Interactions between toxic ( $\mathrm{As}, \mathrm{Cd}, \mathrm{Hg}$, and $\mathrm{Pb}$ ) and nutritional essential ( $\mathrm{Ca}, \mathrm{Co}, \mathrm{Cr}, \mathrm{Cu}, \mathrm{Fe}, \mathrm{Mn}, \mathrm{MO}, \mathrm{Ni}$, Se, $\mathrm{Zn}$ ) elements in the tissues of cattle from NW Spain. Biometals 17: 389-397. Link: https://bit.ly/2UlaGXc

21. Ahamed M, Singh S, Behari JR, Kumar A, Siddiqui MKJ (2007) Interaction of lead with some essential trace metals in the blood of anaemic children from Lucknow, India. Clin Chim Acta 377: 92-97. Link: https://bit.ly/2AEvmIX

22. Malekirad AA, Oryan S, Fani A, Babapor V, Hashemi M, et al. (2010) Study on clinical and biochemical toxicity biomarkers in zinc-lead mine workers. Toxicol Ind Health 26: 331-337. Link: https://bit.ly/2Y2P0qN

23. Olewinska E, Kasperezyk A, Kapka L, Kozlowska A, Pawlas N, et al. (2010) Levels of DNA damage in lead-exposed workers. Ann Agric Environ Med 17 231-236. Link: https://bit.ly/2BaQCpq

24. Kasperezyk A, Prokopowicz A, Michal D, Pawlas N, Kasperezyk S (2012) The effect opf occupational lead exposure on blood levels of zinc, iron, copper, selenium and related proteins. Biol Trace Element Res 150: 49-55. Link: https://bit.ly/2UMOP2D

Citation: Tilako BH, Ogbodo SO, Okonkwo IN, Nubila IN, Shuneba IL, et al. (2020) Distribution and interactions of priority heavy metals with some antioxidant micronutrients in inhabitants of a lead-zinc mining community of ebonyi state, Nigeria. Adv Toxicol Toxic Effects 4(1): 011-0017.

DOI: https://dx.doi.org/10.17352/atte.000009 
25. American Public Health Association (APHA) (1998) Direct air acetylene flame method, standard method for examination of metals. $20^{\text {th }}$ edn.

26. Abdel Moneim AE, Dkhil MA, Al-Quraishy S (2011) Effects of flaxseed oil on lead acetate induced neurotoxicity in rats. Biol Trace Element Res 144: 904 913. Link: https://bit.ly/2C1TBkw

27. Barbosa F, Tanus-Santos JE, Gerlach RF, Parsons PJ (2005) A critical review of biomarkers used for monitoring human exposure to lead: advantages, limitations, and future needs. Environ Health Perspect 113: 1669-1674. Link: https://bit.ly/3e4nj6L

28. Ibeh N, Aneke J, Okocha C, Okeke C (2016) The influence of occupational lead exposure on haematological indices among petrol station attendants and automobile mechanics in Nnewi, South-East Nigeria. J Environ Occup Sci 5: 1-6. Link: https://bit.ly/30lfuji

29. Ji X, He H, Ren L, Liu J, Han C (2014) Evaluation of blood zinc, calcium and blood lead levels among children aged 1-36 months. Nutricion Hospitalaria 30: 548-551. Link: https://bit.ly/2Y0GI8f

30. Ogbodo SO, Oti ME, Okeke AC, Okafor CS (2013b) Pneumoconiosis among quarry workers in a metropolitan town in Southeastern Nigeria. Intern $\mathrm{J}$ Environ Sci 3: 1437-1445. Link: https://bit.ly/30H9xD6

31. Wang S, Shi X (2001) Molecular mechanisms of metal toxicity and carcinogenesis. Mol Cell Biochem 222: 3-9. Link: https://bit.ly/2UHszpi

32. Beyersmann D, Hartwig A (2008) Carcinogenic metal compounds: recent insight into molecular and cellular mechanisms. Arch Toxicol 82: 493-512. Link: https://bit.ly/3e2Dh0Z

33. Yedjou GC, Tchounwou PB (2008) N-acetyl-cysteine affords protection against lead-induced cytotoxicity and oxidative stress in human liver carcinoma (HepG2) cells. Int J Environ Res Public Health 4: 132-137. Link: https://bit.ly/2MVRn8H

34. Patlolla A, Barnes C, Yedjou C, Velma V, Tchounwou PB (2009) Oxidative stress, DNA damage and antioxidant enzyme activity induced by hexavalent chromium in Sprague Dawley rats. Environ Toxicol 24: 66-73. Link: https://bit.ly/2AB3zsS

35. Weihong XU, Wenyi LI, Jianping HE, Singh B, Zhiting X (2009) Effects of insoluble $\mathrm{Zn}, \mathrm{Cd}$, and EDTA on the growth, activities of antioxidant enzymes and uptake of $\mathrm{Zn}$ and $\mathrm{Cd}$ in Vetiveria zizanioides. J Environ Sci 21: 186-192. Link: https://bit.ly/2Bd5uUc

36. Stawarz R, Formicki G, Massányi P (2007) Daily fluctuations and distribution of xenobiotics, nutritional and biogenic elements in human milk in Southern Poland. J Environ Sci Health A Tox Hazard Subst Environ Eng 42: 1169-1175. Link: https://bit.ly/3eeVWqo

37. Wang Y, Ou YL, Liu YQ, Xie Q, Liu QF, et al. (2012) Correlations of trace element levels in the diet, blood, urine, and feces in the Chinese male. Biol Trace Element Res 145: 127-135. Link: https://bit.ly/2XZC3y1

38. Hegazy AA, Manal MZ, Manal AA, Amal AM, Raya AS (2010) Relation between anaemia and blood levels of lead,copper, zinc and iron among children. Biomed Res 3: 133. Link: https://bit.ly/3fnMNMp

39. Mehdi JK, al-Imarah EJ, al-suhail AA (2000) Levels of some trace metals and related enzymes in workers at storage-battery factories in Iraq. East Mediterranean Health J 6: 76-82. Link: https://bit.ly/2MYXvNo

40. Garrick MD, Dolan KG, Horbinsky C, Ghio AJ, Higgins D, et al. (2003) DMT1: A mammalian transporter for multiple metals. Biometals 16: 41-54. Link: https://bit.ly/3d0b7SX
41. Romeyn M (1998) Vitamins, minerals and trace elements.

42. Hafeez A, Mehmood, Mazhar F (2005) Oral zinc supplementation in pregnant women and its effect on birth weight: a randomized controlled trial. Arch Dis Children (Fetal and Neonatal Edition) 90: F170-F171. Link: https://bit.ly/37vYwpz

43. Hanachi P, Golkho S, Norrozi M (2008) The association of serum zinc levels with socio-demographic factors, red and white blood cells count in pregnant women. J Appl Sci 8: 4679-4683. Link: https://bit.ly/2MZy5iA

44. Osendarp SJ, West CE, Black RE (2003) The need for maternal zinc supplementation in developing countries: an unresolved issue. J Nutr 133 817s-827s. Link: https://bit.ly/37u0KG5

45. Prasad AS (2003) Zinc deficiency. $\mathrm{Br}$ Med J 326: 409-410. Link: https://bit.ly/3fnvtaw

46. Pathak P, Kapil U, Dwivedi SN, Singh R (2008) Serum zinc levels amongst pregnant women in a rural block of Haryana State, India. Asia Pacific $\mathrm{J}$ Clin Nutr 17: 276-279. Link: https://bit.ly/2UJXEJ0

47. Harless W, Crowell E, Abraham J (2006) Anaemia and neutropenia associated with copper deficiency of unclear etiology. Am J Haematol 81: 546-549. Link: https://bit.ly/2YBkDXB

48. Hsu PC, Guo LY (2002) Antioxidant nutrients and lead toxicity. Toxicology 180 33-44. Link: https://bit.ly/2UlcXSe

49. Cengiz B, Söylemez F, Oztürk E, Cavdar AO (2004) Serum zinc, selenium, copper, and lead levels in women with second-trimester induced abortion resulting from neural tube defects: a preliminary study. Biol Trace Element Res 97: 225-235. Link: https://bit.ly/2AExK2n

50. Qian ZM, Xiao DS, Wang Q, Tang PL, Pu YM (1997) Inhibitory mechanism of lead on transferrin-bound iron uptake by rabbit reticulocytes: a fractal analysis. Mol Cell Biochem 173: 89-94. Link: https://bit.ly/3hsQwua

51. Klauder DS, Petering HG (1975) Protective value of dietary copper and iron against some toxic effects of lead in rats. Environ Health Perspect 12: 77-80. Link: https://bit.ly/37vZLVL

52. Miller GD, Massaro TF, Massaro EJ (1990) Interaction between lead and essential elements: a review. Neurotoxicology 11: 99-119. Link: https://bit.ly/3hqCNE1

53. Luo H, Li H, Zhang X, Fu J (2011) Antioxidant responses and gene expression in perennial ryegrass (Lolium perenne L.) under cadmium stress. Ecotoxicology 20: 770-778. Link: https://bit.ly/2Y258Jd

54. Luo Y, Yang Y, Hu L, Liu H, Xu Q (2015) Exogenous glycinebetaine alleviates the detrimental effect of $\mathrm{Cd}$ stress on perennial ryegrass. Ecotoxicology 24 1330-1340. Link: https://bit.ly/2Bd7fkg

55. Rabelo FHS, Borgo L (2016) Changes caused by heavy metals in micronutrient content and antioxidant system of forage grasses used for phytoremediation: an overview. Cienc Rural 46. Link: https://bit.ly/30HbhMB

56. Sahebi Z, Mozhgan E, Riza M, Famaz S, Tahere E, et al. (2018) Examination of relationship between mercury rate with zinc and copper changes in muscle tissue of otolithes rubber in Manshahr Port - the Persian Gulf. J Water Chem Technol 40: 177-183.

57. Brzoska MM, Jakoniuk JM (2001) Interaction between Cadmium and zinc in organism. Food Chem Toxicol 39: 967-980. Link: https://bit.ly/3e2FQQX

58. Counter SA, Buchanan LH, Orrega F, Rifai N (2000) Blood lead and haemoglobin levels in Andean children with chronic lead intoxication. Neurotoxicology 21 301-308. Link: https://bit.ly/3fnJm8t

Copyright: (C) 2020 Tilako BH. This is an open-access article distributed under the terms of the Creative Commons Attribution License, which permits unrestricted use, distribution, and reproduction in any medium, provided the original author and source are credited.

Citation: Tilako BH, Ogbodo SO, Okonkwo IN, Nubila IN, Shuneba IL, et al. (2020) Distribution and interactions of priority heavy metals with some antioxidant micronutrients in inhabitants of a lead-zinc mining community of ebonyi state, Nigeria. Adv Toxicol Toxic Effects 4(1): 011-0017.

DOI: https://dx.doi.org/10.17352/atte.000009 